Big Doctoring in America

$\Longleftarrow$ 
BY THE SAME AUTHOR

White Coat, Clenched Fist:

The Political Education of an American Physician

Vital Signs:

A Young Doctor's Struggle with Cancer

Plagues and Politics:

The Story of the United States Public Health Service 


\section{Big Doctoring in America}

Profiles in Primary Care

Fitzhugh Mullan, M.D.

Photographs by John Moses

UNIVERSITY OF CALIFORNIA PRESS

Berkeley • Los Angeles • London

THE MILBANK MEMORIAL FUND

New York 
The Milbank Memorial Fund is an endowed national foundation that engages in nonpartisan analysis, study, research, and communication on significant issues in health policy. In the Fund's own publications, in reports or books it publishes with other organizations, and in articles it commissions for publication by other organizations, the Fund endeavors to maintain the highest standards for accuracy and fairness. Statements by individual authors, however, do not necessarily reflect opinions or factual determinations of the Fund.

University of California Press

Berkeley and Los Angeles, California

University of California Press, Ltd.

London, England

(C) 2002 by the Regents of the University of California

Copyright acknowledgments appear on page vi.

Library of Congress Cataloging-in-Publication Data

Mullan, Fitzhugh.

Big doctoring in America: profiles in primary care /

by Fitzhugh Mullan.

p. cm. (California/Milbank books on health and the public ;5)

Includes bibliographical references and index.

ISBN o-520-22670-4 (cloth : alk. paper)

I. Primary care (Medicine)-United States.

[DNLM: I. Primary Health Care-trends-United

States-Personal Narratives. 2. Family Practice-trendsUnited States-Personal Narratives. W $84.6 \mathrm{M95} 8 \mathrm{~b}$

2002] I. Title. II. Series.

$$
\begin{aligned}
& \text { R729.5.G4 } \cdot \mathrm{M} 85 \quad 2002 \\
& 362 . I^{\prime} 0973-\mathrm{dc2} I
\end{aligned}
$$

2001005492

Manufactured in the United States of America

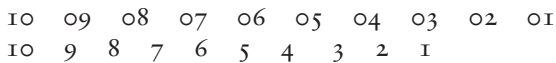

The paper used in this publication is acid-free. It meets the minimum requirements of ANSI/NISO Z39.48-I992 (R I997) (Permanence of Paper). 
For Caroline 
Portions of this work were published previously in the Journal of the American Medical Association and are reprinted here by permission: "Profiles in Primary Care," Vol. 279, No. I4, 8 April I998, I I I 5; "Eugene McGregor, M.D.: A Legacy of General Practice," Vol. 279, No. I4, 8 April I998, I I I7-20; "Connie Adler, M.D.: Living Rural Medicine," Vol. 279, No. 22, I0 June I998, I833-36; "Linda Headrick, M.D.: Seeking a Common Language in Primary Care," Vol. 280, No. 7, I9 August I998, 655-58; "Selma Deitch, M.D., M.P.H.: Children First," Vol. 280, No. 2I, 2 December I998, I867-7I; and "Sam Ho, M.D.: Idealist, Innovator, Entrepreneur," Vol. 28 I, No. Iо, ıо March I999, 947-5I. () I998-99, American Medical Association.

Additional portions were published on the World Wide Web by the Medscape Service (http://www.medscape.com): "Neil Calman, M.D.: Urban Warrior, New York, New York," 25 January 200I; "Therese Hidalgo, R.N., F.N.P.: Proud to Be a Nurse, Belen, New Mexico," I7 January 200I; "Janelle Goetcheus, M.D.: Doctor Succor, Washington, D.C.," I 9 March 200I; and "Carl Toney, P.A.: Building a New Profession in Portland, Maine," 2 March 200 I. 